\title{
The electoral success of the Movimento 5 Stelle: An example of a left populist vote?
}

\author{
Marc Hooghe ${ }^{1}$, Jennifer Oser ${ }^{2, *}$ \\ 1 Centre for Citizenship and Democracy, University of Leuven, Leuven, Belgium \\ 2 Department of Politics and Government, Ben-Gurion University of the Negev, Israel \\ * E-Mail: oser@post.bgu.ac.il; oser@post.harvard.edu
}

\begin{abstract}
The Movimento 5 Stelle in Italy is often cited as an example of a European trend toward the rapidly increasing electoral appeal of populist parties. This article assesses the voting motives of the Movimento electorate in comparative perspective, based on the 2012 European Social Survey. The findings show that, in contrast to the populist electorate in other European countries, Movimento voters are not motivated by anti-immigrant sentiments or by left-right ideology. Rather, Movimento voters are motivated by a negative evaluation of the functioning of the political system, and the concluding discussion relates these findings to recent political history in Italy.
\end{abstract}

\section{Keywords:}

populism; Movimento 5 Stelle; European Social Survey; Italy

\section{Linkspopulismus auf Erfolgskurs: Eine Analyse am Beispiel des Wahlerfolgs des Movimento 5 Stelle}

\section{Zusammenfassung}

Das Movimento 5 Stelle wird oft als Beispiel herangezogen für den europäischen Trend eines schnell wachsenden Erfolges populistischer Parteien. In diesem Artikel werden, in einer vergleichenden Studie anhand des European Social Survey von 20I2, die Gründe untersucht, aus welchen sich die Wähler de Movimento für diese Partei entschieden haben. Die Ergebnisse zeigen, dass die Wähler des Movimento, im Gegensatz zur Wählerschaft anderer populistischer Parteien in Europa, nicht durch Fremdenfeindlichkeit oder durch rechte Ideologien zur Stimmabgabe für das Movimento motiviert werden. Vielmehr treffen Movimento Wähler ihre Wahlentscheidung auf Grund negativer Bewertungen des politischen Systems. Die abschließende Diskussion verknüpft diese Ergebnisse mit den jüngsten politischen Ereignissen in Italien.

\section{Schlüsselwörter:}

Populismus, Movimento 5 Stelle, European Social Survey, Italien

\section{Acknowledgment:}

The authors wish to thank the European Research Council for the ERC Advanced Grant 295920 on democratic linkage between citizens and the state.

The authors have declared that no competing interests exist. 


\section{Introduction}

The rapid rise of the Movimento 5 Stelle in recent Italian elections has been considered a challenge for political science and electoral research (Bordignon \& Ceccarini 20I3). While the party was founded only in 2009, it already gained a considerable appeal in the 2010 regional and the 2012 local elections, and this breakthrough was further consolidated in the 2013 national elections. This electoral success has been explained by invoking a number of elements (Caruso 2015). First, and maybe most importantly, is the appeal of the charismatic leader of the party, Beppe Grillo, who succeeded in turning his strong popular profile into a political and electoral movement, mobilizing a large proportion of voters. Part of this success is due to the fact that Grillo and his party managed to use the internet and other electronic media much more effectively than other political parties in Italy (Bentivegna 2014; Biorcio 2014). The organizational structure of the party, with its emphasis on a lack of a well-developed organization and its focus on the personal role of Beppe Grillo, has been mentioned as a key element for the electoral success of the party (Vignati 2015). The bold use of political rhetoric also partly explains why the Movimento managed to attract a large proportion of voters in a relatively short period.

While various studies have already been published on the personality of the leader of the Movimento, its programme and its electoral strategy, in the current paper we want to shift the focus by investigating the profile of the voters for the Movimento. More specifically, we will compare the electorate of the Movimento with that of other populist parties in Europe. This will allow us to determine to what extent the Movimento really fits into this party family, or whether the party succeeds in carving out its own electoral niche: can the Movimento be considered a typical example of a populist party, or are there specific characteristics of the electorate of this party? In the literature, it is usually assumed that in Europe, populist parties clearly belong to the right side of the political spectrum, with the Austrian FPÖ as an obvious example (Marquart 2013). Recently, however, parties like Podemos in Spain or Syriza in Greece have challenged this notion by presenting a more "left wing" profile of populist parties. Since the Italian Movimento is one of the first and most successful examples of this allegedly left wing exponent of population, we have access to survey data that allow us to investigate whether in the European context, we can actually distinguish a populist vote that is not driven by anti-immigrant sentiments or a negative attitude toward the process of European integration. Our main research question therefore is: can the Movimento 5 Stelle be considered as a distinct form of populism, with distrust and dissatisfaction serving as voting motives, but without an element of anti-immigrant sentiments and nationalism? As we rely on survey data on voting motives, it should be clear that an analysis of the party program or the rhetoric of the party elite falls outside the scope of the current paper.

\section{Literature}

In the literature a wide array of definitions have been offered to arrive at a better understanding of the success of populist parties. Despite the stark differences in these definitions, they converge on one basic idea, namely that populist parties claim to express the interest of the population (or at least of major groups within the population) in direct opposition to the way the political elite is responsible for routine decisionmaking (Jagers \& Walgrave 2007). A hostile attitude toward the political elite, which is seen as alienated from what the majority of the population wants or needs, can therefore be considered as the basic ideology of the populist political parties (Taggart 2000). From this perspective, populism has been labelled as a correction to the current system of representative democracy by arguing for a more direct involvement of citizens in public decision-making processes. Taking the arguments of populist parties seriously, therefore, might even lead to more inclusive forms of political participation, and Kaltwasser (20I2, p. 200) in this respect has argued: "when a society is characterized by high levels of economic, political and social exclusion, populism is a method through which disadvantaged groups may give their voice and lead to the implementation of policies that they prefer.' Populism therefore is basically expressing an opposition between the 'sincere' preferences of the population as a whole, which are considered to be counteracted by the functioning of the political elite. A negative evaluation of the functioning of the political system, therefore, should be an important reason to vote for populist parties.

Although it has been argued that a hostile attitude toward the political elite is the main, or sometimes even the only, defining element of populism (Akkerman, Mudde \& Zaslove 2014), it is clear that other elements also play a role in this regard. Kriesi et al. (2012) have argued that populism should be seen as the political expression of those who stand to lose as a result of structural transformations of Western societies. This broad concept of populist support implies that there is not just a single coherent populist ideology, but rather that various groups may lose out for different reasons, and therefore also might have different resulting ideologies and political options (Alonso \& Kaltwasser 2015). Priester (2012) and Kriesi (2014) introduced a distinction between more left-wing oriented forms of populism and more right-wing oriented forms. While left-wing populists are more inclined 
to pay attention to inequality and economic exclusion, for right-wing populists the focus is on nationalism, and on emphasizing the opposition between ingroup and outgroup cultural identities. In both cases, however, a populist vote is first and foremost considered to be an expression of discontent: populism is hardly ever considered to be positive voting choice.

In the case of left-wing populism, the focus is on fighting forms of inequality and social exclusion. The groups that are most vulnerable on the labor market will be opposed to various attempts to liberalize labor market regulations and to scale down on social security protection. Here too, the interests of 'ordinary citizens' are perceived to be violated by decision-making of the political elite. Since there is a strong concern about rising levels of inequality in Western Europe, the main defining characteristic of this left-wing form of populism therefore should be a concern about rising levels of inequality (Bermeo \& Bartels 20I4). Combining this concern with the anti-elitist core of populist ideology would imply that the political elites are being held responsible for failing to protect the population from rising inequality and poverty (Kriesi 20I4).

The right-wing interpretation of populism, on the other hand, stresses the potential negative impact of rising ethnic diversity. Populists tend to portray the population as a homogeneous group, with largely similar interests. This form of group thinking can also be associated with a negative attitude toward outsiders who are blamed for the threat they pose with regard to increased competition on the job and housing market (Dancygier \& Donnelly 20I4). In that case, populism can easily be combined with a rhetoric against immigrant groups and policies of multiculturalism. Here, the focus is less on the antagonism between the 'ordinary citizens' and the political elite, but rather on the alleged homogeneity of the population with regard to cultural and normative affairs.

In recent overviews of the rise of populist voting in Europe, the Movimento 5 Stelle is often quoted as a prime example of a highly successful populist party (Rooduijn, de Lange \& Van der Brug 20I4; Zhirkov 20I4). ${ }^{\mathrm{P}}$ As in other countries, populist parties in Italy reject the institutional status quo, and they depart from an opposition between the democratic will of the population and the way mainstream political parties and institutions operate. However, within this literature, the Movimento 5 Stelle does pose an important theoretical challenge. The party has been described as a distinct form of populism: while to a large extent it shares the populist

I Within the literature, there is some disagreement on the question of whether the party of former prime minister S. Berlusconi (Forza Italia, and later Popolo delle Libertà) should also be considered a populist party. In order to investigate this possibility, we also conducted a separate analysis on voting motives for this party. rhetoric that is built on a distrusting attitude toward the political elite, the party does not seem to share with the other members of that party family the same view with regard to immigration and diversity (Lanzone 20I4). The question therefore remains whether the Movimento really fits into the populist party family, or whether this party should be considered as a very specific form of left-wing populism - without the element of anti-immigrant rhetoric that is such an important element in most populist parties.

In various Western European countries populist political parties have been remarkably successful in recent elections (Kriesi 20I4). Even in the Scandinavian countries, which are typically portrayed as a bulwark of high trust and more tolerant attitudes, these parties have gained firm ground in national parliaments and have quite rapidly become an established part of the party system (Mudde \& Kaltwasser 2012). During the 20I4 European elections, populist and anti-immigrant parties scored a major breakthrough and they are now one of the major political party groups within the European Parliament.

In recent years, various studies have tried to determine the motivations for a populist vote, and these efforts have led to a wide array of possible voting motives. Recurring topics, however, are a critical and distrusting attitude toward the political system, and a misapprehension toward (increasing) cultural and ethnic diversity in European societies. First, low levels of political trust are a major determinant of a populist vote: distrust toward the most important institutions of liberal democracy serves as a powerful incentive to vote for a challenger party (Hooghe, Marien \& Pauwels 20II). This negative attitude is not just limited to the main institutions of representative democracy, but also includes the functioning of what are considered to be mainstream parties (Schumacher \& Rooduijn 2013). The rhetoric of these parties routinely stresses the point that they express in a sincere manner the value priorities of the population, against the prevailing elite consensus on how the political system should operate (Jagers \& Walgrave 2007). It can therefore be assumed that a negative evaluation of the way the political system operates is a first and major incentive for a populist vote. Second, socio-economic exclusion and the presence of ethnic minorities in the community, too, have been shown to have an effect on the propensity to vote for populist challenger parties (Rydgen \& Ruth 2013). The idea is that mainly citizens who feel at risk for the alleged negative consequences of increasing globalization in Western societies will have the feeling that mainstream political parties are no longer motivated to protect their cultural or socioeconomic position. As a result, immigration has become a hotly debated issue in quite some elections as immigrants are often considered as a potential threat for one's 
own position on the labour and housing market (Kriesi et al. 20I2).

While thus far, in most of the literature there is a focus on single-country studies, combining these national studies suggests that various voting motives might be at play, and that these voting motives might even interact. In practice a mixture of various elements is conducive toward this kind of voting behavior, including distrust toward the more mainstream parties, and a fear of immigration and diversity. Populist voters often lack the confidence that the mainstream parties and political institutions will protect them from the adverse consequences of increasing ethnic diversity (Webb \& Bale 2014). This rather diverse array of possible voting motives renders it all the more difficult to pinpoint the exact ideological profile of populist parties.

A complication for the comparative research on determinants of populist voting is that there is strong variation between countries in the electoral success of these political parties. While it can be assumed that some kinds of social tensions are almost universal (e.g., tensions as a result of economic globalization or of increasing cultural and ethnic diversity), the electoral appeal of these parties also depends on characteristics of the electoral system and on the country-specific strategies of political entrepreneurs. In some countries these entrepreneurs clearly have been successful, partly because of the way they have gained access to the mass media, while in other countries such entrepreneurs remain virtually absent. Almost self-evidently, characteristics of the electoral system too might have an impact on the viability of populist challengers (van Kessel 2OII). Italy too might be considered as a political system that is conducive to a populist vote: ever since the I990s, the Italian party system has been very volatile, with new parties and coalitions emerging on both the left and the right side of the political spectrum without apparently leading to stable alliances (Druke 20I2; Newell 20IO). This ongoing turmoil implies that traditional stable alignments have become obsolete to a large extent, which would mean that a rather large group of Italian voters would be structurally 'available' for new challenger parties.

The question then becomes to what extent the Movimento 5 Stelle fits into this ideal type of populist voting. The party elite itself stresses the fact that it does not want to contribute to a hostile climate toward immigrants and refugees (Colloca \& Corbeta 20I4), and that would imply that it diverts from an important common theme within the populist party family in Europe. Despite this position of the party officials, however, it is possible that for voters, this kind of negative attitude toward diversity still might function as a voting motive. Therefore, in this paper, our goal is to ascertain what are the voting motives for the Movimento. By comparing the voters for this party with those of other populist parties in Europe, we can determine to what extent the party fits into the standard definition of the populist party family. While in the literature on voting behaviour in Latin America, a distinction is often introduced between left wing and right wing populist voting, this distinction is but weakly present in the European context. The question therefore remains whether the Movimento could be seen as an example of left wing populism. The scope of this paper does remain limited to voter motives, and we therefore do not wish to make any statements on party manifestoes or party programs as this falls clearly outside the scope of the current article.

\section{Data and methods}

Following the literature on potential populist voting motives, we include a number of possible explanations for populist voting. A populist vote can be explained by a negative evaluation of the democratic functioning, by political distrust, and by anti-immigrant sentiments. The analysis is based on the European Social Survey in 2012, which allows us to trace the motives of voters for these parties (ESS Round 6, 2012). While there are numerous studies on the ideology and the party programs of populist parties (Rooduijn \& Pauwels 20II), few studies have focused on the voting motives of populist voters. The fact that we rely on survey data, however, also implies that we can only focus on those parties that are represented in the European Social Survey, and therefore we cannot include populist parties that have a very limited electoral appeal, or whose voters, for various reasons, are not well represented in the European Social Survey. Given the strong electoral appeal of the Movimento 5 Stelle, however, it is well represented in the Italian sample of the 2012 ESS, and it therefore offers more than sufficient empirical data to investigate motives for populist voting. The downside of relying on survey data is of course that it does take some time to gather reliable population data in this manner, so that we cannot make any statements on the most recent developments in this regard.

If populist voting first of all can be seen as an expression of discontent, an evaluation of the functioning of the political system serves as a first obvious voting motive. In the ESS questionnaire, respondents were asked to rate the functioning of the political system in their country on II specific items, ranging from having free and fair elections, allowing media to criticize the government, to protecting citizens from poverty. This evaluation battery is a major innovation within ESS 2012. First, it can be observed that Italian respondents indeed have a very negative assessment of the way their political system functions (Table I). Of the II statements, for 
eight of them the average is below five on a scale that ranges from zero to ten. For some items, the scores are dramatically low, e.g., with regard to the efforts of the government to protect citizens from poverty. Scores are also very low, however, with regard to the capacity to punish government during elections, and the question on whether different political parties offer clear alternatives to one another. Italian public opinion clearly has a very negative view on the capacity of electoral politics to bring about change. Equally worrisome is the very low score on the question of whether Italian courts treat everyone in the same manner. This highly negative assessment becomes even clearer when we compare the average of the Italian sample with that of the ESS sample as a whole. For each and every item, the Italian mean score is a full point below the ESS average. With regard to the functioning of courts and the democratic potential of elections and parties, the distance is even larger, and Italy scores exceptionally low on these items. If we assume that populist parties derive their appeal mainly from discontent, it is very clear that there is a huge potential of dissatisfied voters in Italy.

If we subsequently explore the structure of these evaluations, both in the full sample, as in the specific Italian sample, we find a clear two factor solution. A first factor is focused on the evaluation of social rights, as the single most important item for the factor is the question whether government protects citizens from poverty. A second factor is focused more clearly on the electoral and political process, as the most important items here are whether the media and opposition parties can criticize government. The results for the factor analysis in Italy are roughly in line with those for the entire ESS sample, although it has to be noted that among Italian respondents, the protection of minority rights loads more strongly on the first factor. So while Italian respondents clearly are more negative in their evaluation of the political system than most other respondents in Europe, we can conclude that the structure of their evaluations is largely the same.

Table 1: Evaluation Battery in ESS 2012

\begin{tabular}{|c|c|c|c|c|c|c|}
\hline & \multicolumn{3}{|c|}{ Italy } & \multicolumn{3}{|c|}{ ESS } \\
\hline & Mean & Factor I & Factor II & Mean & Factor I & Factor II \\
\hline $\begin{array}{l}\text { National elections in my country are free } \\
\text { and fair }\end{array}$ & 5.88 & .370 & .514 & 6.97 & .376 & .648 \\
\hline $\begin{array}{l}\text { Different political parties offer clear } \\
\text { alternatives to one another }\end{array}$ & 3.68 & .634 & .329 & 5.54 & .423 & .492 \\
\hline $\begin{array}{l}\text { Opposition parties are free to criticize } \\
\text { the government }\end{array}$ & 6.52 & .071 & .849 & 7.38 & .093 & .870 \\
\hline $\begin{array}{l}\text { The media are free to criticise the } \\
\text { government }\end{array}$ & 6.13 & .075 & .873 & 7.24 & .135 & .868 \\
\hline $\begin{array}{l}\text { The media provide citizens with reliable } \\
\text { information to judge the government }\end{array}$ & 4.61 & .503 & .513 & 5.90 & .369 & .603 \\
\hline $\begin{array}{l}\text { The rights of minority groups are } \\
\text { protected }\end{array}$ & 4.56 & .621 & .326 & 6.21 & .377 & .517 \\
\hline The courts treat everyone the same & 3.53 & .740 & .086 & 4.89 & .707 & .357 \\
\hline $\begin{array}{l}\text { Governing parties are punished in } \\
\text { elections when they have done a bad job }\end{array}$ & 3.14 & .667 & .193 & 5.45 & .601 & .344 \\
\hline $\begin{array}{l}\text { The government protects all citizens } \\
\text { against poverty }\end{array}$ & 2.61 & .875 & .074 & 3.91 & .880 & .185 \\
\hline $\begin{array}{l}\text { The government explains its decisions to } \\
\text { voters }\end{array}$ & 3.32 & .784 & .233 & 4.59 & .840 & .245 \\
\hline $\begin{array}{l}\text { The government takes measures to } \\
\text { reduce differences in income levels }\end{array}$ & 2.78 & .867 & .077 & 3.94 & .873 & .160 \\
\hline $\mathrm{N}$ & 909 & & & 50851 & & \\
\hline Eigen value & & 5.11 & 1.54 & & 5.51 & 1.39 \\
\hline Expl. Variance & & 46.47 & 13.95 & & 50.04 & 12.68 \\
\hline
\end{tabular}

Notes: Average scores on evaluation question, for the ESS sample in Italy, and for the entire ESS sample 2012. Factor analysis with varimax rotation, both for the Italian sample and the entire ESS sample. 
Second, an important motive for populist voting is a lack of confidence in the established political institutions (Fuchs, Gabriel \& Völkl 2002). Therefore, we also investigate trust in political institutions as a potential voting motive. Lack of political trust has been shown to be one of the main voting motives for populist antisystem parties. In the ESS, five national political institutions are listed for which respondents can express their level of trust on a zero to ten scale. These institutions are parliament, the legal system, police, politicians and political parties. In line with theoretical expectations and previous research (Hooghe 20II), these five items prove to be a one-dimensional scale (Eigenvalue 3.626, explained variance 72.52 per cent) with a strong internal coherence (Cronbach's $\alpha$.9I). For trust in political institutions, too, Italian scores are generally below the European averages, with exceptionally low scores for trust in politicians and political parties. For the Italian case, it is quite telling that especially the trust in politicians and political parties is much lower than in other European countries. It would be incorrect, however, to isolate these two items as the factor analysis clearly shows that in Italy too, all political trust items load on the same latent variable. One might speculate in this regard that the extremely negative view on politicians and political parties apparently also has an effect on the level of trust in other political institutions. In Italy too, therefore, one could assume a strong potential for populist voting (Table 2).

Table 2: Trust in Political Institutions

\begin{tabular}{|l|c|c|}
\hline Trust in ... & Italy & ESS \\
\hline Parliament & 3.16 & 3.96 \\
\hline Legal System & 4.46 & 4.76 \\
\hline Police & 6.11 & 5.71 \\
\hline Politicians & 1.95 & 3.23 \\
\hline Political Parties & 2.00 & 3.24 \\
\hline Average & 3.54 & 4.18 \\
\hline
\end{tabular}

Notes: Entries are average scores for trust in political institutions on a 0-10 scale. Averages for the Italian ESS and the entire ESS sample.

In order to assess a negative attitude toward immigrants, we include the three item anti-immigrant sentiment scale that is routinely included in the European Social Survey (Semyonov, Raijman \& Gorodzeisky 2006). In general, this is considered to be a valid operationalization of negative attitudes toward ethnic diversity within one's society. Some populist parties have also stressed a negative attitude toward the process of European integration (Aurieamma et al. 2015; Tournier-Sol 2015). In the European Social Survey questionnaire, this Euro- sceptic attitude is only measured with one item about whether or not European integration has gone too far. In countries that are a member of the EU this item can be used to assess a negative attitude toward the process of European integration and the accompanying loss of national sovereignty.

We also include relevant control variables in order to be sure that we do not find any spurious relations. The analysis controls for variables that previously have been shown to have an effect on the propensity to vote for a populist party, such as education level of the respondent, and obvious socio-demographic information like age and gender. Further, we control for generalized trust, placement on a political left-right scale, political interest, and satisfaction with the economy. From a theoretical perspective, we would ideally like to investigate more positive voting motives that are sometimes noted in the literature, such as interest in democratic renewal, or feelings of social cohesion. Since these motives are difficult to measure and analyze empirically in a cross-culturally equivalent manner, we must note that these are important explanations to investigate in future studies.

The dependent variable of the logistic regression analyses is voting behavior as measured in the European Social Survey in 2012 by self-report of the party the respondent voted for in the last general elections. In this survey, it can be observed that the percentage of respondents indicating a populist vote is clearly lower than what we know from electoral results. Partly this can be explained by social desirability, and partly as a result of the fact that the determinants of a populist vote (e.g., lower level of education or less trust), also render it more likely that a populist voter will not take part in the survey. Nevertheless, for seven countries that were included in the ESS, we do have sufficient respondents indicating a populist vote to conduct a viable analysis. We limit ourselves to those political parties that unequivocally can be considered as populist, as indicated by previous research. In Switzerland, the Swiss People's Party (SVP) is included (McGann \& Kitschelt 2005). The Nordic countries are represented with the Danish People's Party, the Finns and the Norwegian Progress Party (Bengtsson et al. 20I4). In France, the Front National is traditionally seen as an extreme right voice (Mayer 1999). Especially since the new party leader Marine Le Pen took office in 20II, this profile has changed somewhat as she more explicitly addresses various topics like social exclusion, anti-immigrant sentiments and the status of the current poitical elite (Mayer 2015; Stockemer \& Amengay 2015). In Italy the Movimento 5 Stelle can be considered as a new but electorally highly successful phenomenon (Colloca \& Corbetta 2014). For the Netherlands, the PVV Freedom Party can be considered as a typical representative of populist parties (van der Pas, de Vries \& 
van der Brug 20I3). In each of these seven countries, the ESS contains a sufficient number of respondents who indicate that they have voted for a populist party (Table 3). The fact that only these seven countries are available implies that the number of level-2 units is too limited to conduct multilevel analysis. We therefore opt to analyze the results in every country separately, which also corresponds to the notion that not every populist party might exert the same attraction for potential voters. Comparing the results across countries should help us to answer the research question of whether voting motives for the Movimento are distinct compared to those for other populist parties in Europe.

Table 3: Populist Voters in ESS 2012

\begin{tabular}{|l|l|c|}
\hline Country & Party & Proportion in ESS \\
\hline Italy & $\begin{array}{l}\text { Movimento 5 } \\
\text { Stelle }\end{array}$ & 13.1 \\
\hline Switzerland & SVP & 8.8 \\
\hline Denmark & DFP & 7.1 \\
\hline Finland & The Finns & 9.2 \\
\hline France & Front National & 7.2 \\
\hline Netherlands & PVV & 4.9 \\
\hline Norway & FP & 8.1 \\
\hline
\end{tabular}

Notes: Source is the ESS 2012. Party voted for in the last national elections.

We have to acknowledge here that there is an ongoing debate in the literature on the question whether the Movimento should be considered as the only, or the main example of a populist party in Italy. The rhetoric used by Silvio Berlusconi and his party 'Popolo delle Libertà' $(\mathrm{PdL})$ also includes various elements that are usually considered to be part of the populist challenge. Simultaneously, however, it should be stressed that it has also for a long time been a governing party in Italy, so therefore, it does not seem obvious to consider this as a system-challenging populist party. However, in order to arrive at a valid comparison, in a distinct analysis we also investigated voting motives for this party, so this can be compared with the voting motives of the Movimento electorate. $^{2}$

2 The regional party 'Lega Nord' might also be considered as an example of a populist party. In the ESS survey, however, only eight respondents indicated a vote for this party, which is not sufficient for a valid analysis.

\section{Results}

The results of the different logistic regression analyses are quite telling (Table 4). Despite the obvious differences between the various countries and political parties, we do observe some clear patterns. First of all, we can observe that the models have a fairly high level of explained variance, ranging from 13 to 32 per cent. The models are thus quite good in explaining why respondents have opted for a populist party. This is in line with earlier studies which showed that populism is a very distinct political preference that can be investigated in a rather convincing manner.

First we review the evaluation scores. Both for the social rights as for the political process evaluation of respondents' own country, most results are non-significant. Quite striking, the major exceptions here are Italy and the Netherlands. In Italy, voters for the Movimento 5 Stelle are clearly motivated by a negative evaluation of the political processes in their country, which might be interpreted in the light of the various corruption scandals during the Berlusconi era. Much more than in other countries, therefore, populist voters in Italy are motivated by the fact that they are not satisfied at all by the way the political and legal institutions function in their country. ${ }^{3}$ In the Netherlands, on the other hand, we see a significant effect of the evaluation of how the country deals with inequality and poverty, and here one can relate this to the strong austerity measures that have been taken in that country. In contrast to the Italian case, in the Netherlands we do not find an effect of the evaluation of the political and legal institutions. This battery, therefore, allows us to identify a highly typical Italian feature. Not only are levels of satisfaction with the functioning of these institutions extremely low in Italy compared to other European countries, we also find that the Movimento is indeed the only populist party in Europe that is so strongly driven by disapproval about the way the current institutions operate. Slightly in contrast to the theoretical expectations, we do not find a significant effect of political trust in most countries. Most likely this is a result of the fact that the evaluation battery already captures in a very specific manner the attitude toward the political system. Only for Finland (where on average there is a high level of satisfaction with the way the political system function), we find that the evaluation does not seem to matter, but only the level of political trust.

The concept that there are 'left' and 'right' wing populist parties in Europe is not supported at all by these results. On the contrary: in almost all cases, populist voters

3 A distinct analysis on voting motives for the Popola delle Libertà did not show a significant effect of political (dis)trust, thus substantiating the doubt on whether this party does fit the definition of a populist party. 
Table 4: Determinants of Populist Voting

\begin{tabular}{|c|c|c|c|c|c|c|}
\hline & \multicolumn{2}{|c|}{ Denmark } & \multicolumn{2}{|c|}{ Finland } & \multicolumn{2}{|c|}{ France } \\
\hline & I & II & I & II & I & II \\
\hline $\begin{array}{l}\text { Evaluations } \\
\text { Social Rights } \\
\text { Political Processes }\end{array}$ & $\begin{array}{l}-.255(.197) \\
.195(.205)\end{array}$ & $\begin{array}{l}-.236(.199) \\
.107(.207) \\
\end{array}$ & $\begin{array}{l}-.081(.120) \\
.319(.136)^{*}\end{array}$ & $\begin{array}{l}-.065(.121) \\
.239(.138)\end{array}$ & $\begin{array}{l}.095(.128) \\
-.031(.116)\end{array}$ & $\begin{array}{l}.069(.131) \\
-.041(.117) \\
\end{array}$ \\
\hline Political Trust & $-.445(.203)^{*}$ & $-.377(.205)$ & $-.686(.142)^{\star \star \star}$ & $-.570(.145)^{\star \star \star}$ & $-.485(.157)^{\star \star}$ & $-.408(.160)^{*}$ \\
\hline Gender & $-.323(.257)$ & $-.370(.261)$ & $-.794(.173)^{\star \star \star}$ & $-.778(.176)^{\star \star \star}$ & $-.486(.193)^{\star}$ & $-.530(.195)^{\star *}$ \\
\hline Age & $.016(.007)^{\star}$ & $.016(.007)^{\star}$ & $-.010(.005)^{\star}$ & $-.011(.005)$ & $-.010(.006)$ & $-.010(.006)$ \\
\hline Education & $-.036(.026)$ & $-.032(.027)$ & $-.042(.024)$ & $-.040(.024)$ & $-.011(.031)$ & $-.005(.032)$ \\
\hline Generalized Trust & $.027(.171)$ & $.092(.179)$ & $.208(.124)$ & $.209(.125)$ & $.152(.130)$ & $.182(.133)$ \\
\hline Left Right & $.242(.061)^{\star \star \star}$ & $.254(.061)^{\star \star \star}$ & $-.005(.040)$ & $.012(.041)$ & $.207(.043)^{\star \star \star}$ & $.213(.043)^{\star \star \star}$ \\
\hline Political Interest & $.137(.174)$ & $.184(.175)$ & $-.329(.108)^{\star \star}$ & $-.287(.110)^{\star \star}$ & $.069(.112)$ & $.045(.113)$ \\
\hline Satisfaction Economy & $-.056(.060)$ & $-.046(.061)$ & $.003(.050)$ & $.037(.051)$ & $-.021(.055)$ & $-.023(.056)$ \\
\hline Anti-Immigrant Sentiment & $.840(.151)^{\star * *}$ & $.737(.158)^{\star \star * *}$ & $-.526(.116)^{\star \star \star}$ & $-.356(.122)^{\star \star \star}$ & $-.814(.123)^{\star \star \star}$ & $-.800(.126)^{\star \star \star}$ \\
\hline Euroscepticism & ---- & $.136(.051)^{\star *}$ & --- & $.239(.042)^{\star \star \star}$ & --- & $.065(.040)$ \\
\hline Cte & $-3.773(.931)$ & $-4.691(1.004)$ & $1.213(.641)$ & $-.830(.742)$ & $-2.963(.789)$ & $-3.273(.833)$ \\
\hline Nagelkerke r2 & .285 & .298 & .132 & .168 & .216 & .221 \\
\hline $\mathrm{N}$ & 1406 & 1380 & 1983 & 1971 & 1769 & 1754 \\
\hline
\end{tabular}

\begin{tabular}{|c|c|c|c|c|c|c|}
\hline & \multicolumn{2}{|c|}{ Italy } & \multicolumn{2}{|c|}{ Netherlands } & \multirow[t]{2}{*}{ Switzerland } & \multirow[t]{2}{*}{ Norway } \\
\hline & 1 & II & 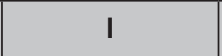 & II & & \\
\hline $\begin{array}{l}\text { Evaluations } \\
\text { Social Rights } \\
\text { Political Processes }\end{array}$ & $\begin{array}{l}.025(.164) \\
-.442(.123)^{\star \star *}\end{array}$ & $\begin{array}{l}.030(.167) \\
-.433(.124)^{\star \star \star *}\end{array}$ & $\begin{array}{l}-.735(.210)^{\star \star \star} \\
-.227(.182)\end{array}$ & $\begin{array}{l}-.6763(.210)^{\star \star} \\
-.230(.184)\end{array}$ & $\begin{array}{l}.102(.183) \\
.095(.153)\end{array}$ & $\begin{array}{r}-.242(.157) \\
.027(.183)\end{array}$ \\
\hline Political Trust & $-.377(.195)^{\star \star}$ & $-.378(.196)$ & $-.321(.214)$ & $-.233(.218)$ & $.088(.186)$ & $-.431(.178)^{*}$ \\
\hline Gender & $-.344(.246)$ & $-.336(.247)$ & $-.692(.362)^{\star \star}$ & $-.671(.264)^{\star *}$ & $.031(.228 /)$ & $-.746(.231)^{* *}$ \\
\hline Age & $-.019(.008)^{*}$ & $-.018(.008)^{*}$ & $-.008(.008)$ & $-.007(.008)$ & $.005(.006)$ & $.002(.006)$ \\
\hline Education & $-.044(.028)$ & $-.045(.028)$ & $-.095(.040)^{\star}$ & $-.089(.041)^{\star}$ & $-.097(.039)^{\star}$ & $-.114(.026)^{* *}$ \\
\hline Generalized Trust & $.129(.153)$ & $.148(.154)$ & $.101(.184)$ & $.090(.184)$ & $.106(.157)$ & $-.109(.161)$ \\
\hline Left Right & $.021(.050)$ & $.017(.050)$ & $.313(.069)^{\star * \star}$ & $.306(.070)^{* * *}$ & $.451(.065)^{* * *}$ & $.483(.062)^{\star * *}$ \\
\hline Political Interest & $-.213(.144)$ & $-.212(.145)$ & $-.376(.163)^{*}$ & $-.344(.163)$ & $-.352(.153)^{*}$ & $-.245(.145)$ \\
\hline Satisfaction Economy & $-.225(.077)^{\star *}$ & $-.223(.078)^{\star \star}$ & $-.062(.075)$ & $-.040(.075)$ & $-.204(.071)^{\star *}$ & $-.041(.062)$ \\
\hline Anti-Immigrant Sent. & $.226(.135)$ & $.276(.150)$ & $-1.066(.199)^{\star * *}$ & $-.935(.208)^{* * *}$ & $-.713(159)^{\star \star \star}$ & $-.634(.142)^{* * *}$ \\
\hline Euroscepticism & --- & $.043(.052)$ & --- & $.138(.062)^{*}$ & --- & --- \\
\hline Cte & $.710(.848)$ & $.524(.878)$ & $-.706(1.074)$ & $-1.848(1.198)$ & $2.050(.982)$ & $-1.765(.887)$ \\
\hline Nagelkerke r2 & .145 & .147 & .300 & .308 & .252 & .319 \\
\hline N & 650 & 639 & 1610 & 1599 & 1126 & 1526 \\
\hline
\end{tabular}

Notes: Entries are the result of logistic regressions, with voting for a populist party as dependent variable. Sign. : ${ }^{*}=<.05 ;{ }^{* *}=<.01 ;{ }^{* * *}=<.001$. 
situate themselves strongly on the right of the political spectrum. As already mentioned, only among the Dutch voters for PVV, we do find an element of concern about economic inequality, but this is certainly not a general rule among European countries. For the Movimento too, we do not find any effect of left-right self placement whatsoever, indicating that voters for the party do not identify as left wing voters. While various studies have suggested the occurrence of a left wing interpretation of populism in Latin America, for the populist parties in Western Europe at least it is clear that this is not the case, and that all the major populist parties can be situated on the right wing side of the political spectrum. Again the Movimento 5 Stelle is distinct, as it does not fit in the pattern of left wing populism that has been documented in Latin America: its voters do not seem to have a specific preference with regard to left-right divisions.

So what does explain a populist vote according to these findings? The major motivations can be summarized in two variables: dissatisfaction with government and anti-immigrant sentiments. Between countries, the specific indicators vary: while in some countries political trust has an effect, in others it is a negative evaluation of the state system. It is clear, therefore, that in some way or another populist voters are discontent with the functioning of the current system, which can be conceptualized as a protest vote.

The second major determinant is anti-immigrant sentiments, which for most populist parties provide rather staggering effects. In countries like the Netherlands, Switzerland and Denmark this is clearly a primary voting motive for a populist party. Again, however, for Italy results are different, and here anti-immigrant sentiments are not a populist voting motive. It is important to note that the control for the state of the economy in the country is significant only in Italy and in Switzerland. The Swiss SVP exception is quite remarkable given the fact that unemployment levels tend to be rather stable in that country. Taken as a whole, however, the findings show that the effect of anti-immigrant sentiments cannot be reduced to an economic threat hypothesis, as if the immigrants will be held responsible for an increased competition on the labor market, and therefore higher unemployment figures. Instead, the effect of anti-immigrant sentiments is rather strong and direct, and does not operate only through a negative assessment of the state of the economy.

Finally, the analyses also allow us to investigate the effects of a hostile attitude toward the process of European integration. Within the group of EU-member states, we repeat the analysis, but this time with the addition of a negative attitude toward Europe as an independent variable. As can be observed, only in Denmark and Finland we do find a clear effect of an Eurosceptic attitude, but the contribution to the explained variance remains rather modest. If we compare the basic models, without Euroscepticism, it can be observed that the two non-EU-members (Norway and Switzerland) show a similar pattern as the EU member countries that we have investigated. In Italy, a hostile attitude toward the European Union does not play any role at all in explaining a populist vote. The Movimento 5 Stelle therefore can be clearly identified as a very distinct form of populism in Europe. In most other European countries, discontent is directed toward either immigrant groups or toward the European Union. In Italy, both voting motives are remarkably absent, and instead a negative evaluation of the national political and legal institutions can explain the bulk of all voting motives for the Movimento. ${ }^{4}$ While it is correct that recently the Movimento leadership has expressed itself more clearly on both of these issues, for the 2012 analysis of voting motives at least, we do not find a meaningful relation. In the light of more recent developments, it remains therefore an open question how these voting motives will evolve in the years ahead.

\section{Discussion}

The major question for this study was to ascertain whether the Movimento 5 Stelle can be considered as a distinct Italian form of a populist party. The answer is that it clearly is. First of all, however, it is striking to note that all the populist parties we could investigate using the ESS dataset indeed have something in common. In each country, we find that discontent is a major driving force for a populist voting. Whether it is discontent about the way politics functions, about immigration, or about the process of European integration, or a combination of these three forms of discontent, it is clear that discontent is a powerful determinant of a populist vote. As noted, it proved difficult to investigate the more positive voting motives that are sometimes mentioned in the literature, so this remains an important topic for future research. The negative sentiments, on the other hand, proved to be quite easy to measure, and the findings show that they are strong voting motives. So a tentative conclusion might be that if there is something like a populist party family, the common feature is first of all a form of discontent about the way societies and political systems currently function.

In addition, however, strong country differences are also present with regard to the object of discontent. The logic behind the prominent forms of discontent in each country is not always straightforward. For example, the OECD figures on immigration and ethnic diversity, show that Norway is in fact a country with a relatively

4 For a vote on the Popola delle Libertà too, no significant effects of these motives were found, indicating that our findings for the Movimento can be generalized to all allegedly populist parties in Italy. 
low level of ethnic diversity. Nevertheless, in Norway anti-immigrant sentiments proved to be the most powerful determinant of populist voting. Further research is needed to explain why some populist parties 'specialise' in certain forms of discontent. In the Norwegian case, a possible explanation might be that until recently, Norway was a very homogeneous society. So although the level of immigration to the country certainly is not exceptional, for a substantial number of native Norwegians, it might not be self-evident to adapt to this new characteristic of their country.

In Italy too, populist voting clearly 'specialises' in one topic, and in this case that is discontent about the functioning of the country's political processes. Given the evidence in prior research of a low level of quality in government in Italy and a high level of corruption, this focus might not come as a surprise. In fact, discontent about the functioning of the political system is so rampant in Italy that there is obviously a large potential for protest or populist voting among the Italian electorate. An equally relevant question, however, is why there is no relation between anti-immigrant sentiments and a vote for the Movimento. Immigration figures to Italy have risen sharply and a number of incidents seem to demonstrate that there is certainly quite some anti-immigrant sentiment present among the Italian population. Even if we include, in a distinct analysis, the voting motives for the Popolo delle Libertà party, anti-immigrant sentiments still do not emerge as a distinct, significant voting motive. Apparently, political entrepreneurs thus far have not been able to capitalize on this sentiment to gather votes. We have to note here that our findings are limited to observations from the year 2012. In the more recent period, some leaders of the Movimento have expressed themselves in a more negative manner on the presence of immigrants in Italy, and the presence of an increased number of asylum seekers since 2015 also has led to various comments from Italian politicians. As in our analysis we limit ourselves to voting motives, it is not yet clear to what extent this elite rhetoric also is related to changing voter motives, and this is something to investigate in the future, if new survey and election data will become available. The theoretical relevance of our findings, however, remains that at least in 2012 the populist vote in Italy apparently was not significantly related to anti-immigrant sentiments, in contrast to the situation in a number of other European countries.

The Italian case, however, also makes clear that simple distinctions do not seem to function all that well. In some of the literature, the Movimento has been considered as an example of left wing populism, exactly because of the absence of anti-immigrant rhetoric (Lanzone 2014). Simultaneously, however, we observe that the voters for this party do not identify as left-wing, so it is obviously wrong to equate the absence of anti- rhetoric sentiments with a leftist political position. The voters who support the Movimento do not seem to have any fixed position on left-right dimensions, but are focused almost exclusively on a negative assessment of the way the Italian political system operates. It also has to be noted that an additional analysis of the ESS data show that a right wing position on the left-right divide is an important determinant for a vote for the Berlusconi-led party Popolo delle Libertà. Given the electoral success of this party, one might wonder whether a clear right wing populist challenger might still be viable in the Italian party system. Because of the dominant position of Popolo delle Libertà, a promising hypothesis for future research is that there would not be another option for new challengers than to stay away from the self-defined right wing electorate.

As we already mentioned in the introduction of this paper, our scope remains limited to the study of voter motives, as previous studies have already led to new insights on the party's leadership, organizational strategy and party manifestoes. Self-evidently, this focus is also an important limitation to the current study: while we can show that Italian populist voters clearly have voting motives that are distinctive from their counterparts in other European countries, we do not know whether the same can be observed if we investigate party strategy. Indeed, it remains unclear whether there is any congruence between voter motives and party program. For example, while the Movimento leadership has expressed a skeptical attitude toward the functioning of the European Union, especially in the more recent era, we do not find any indication that a negative attitude toward European integration would be a significant voting motive, at least not in 2012. Theoretically this is an interesting finding as it suggests that party program and voting motives are not necessarily identical. For future research, therefore, our recommendation would be that it would be incorrect to limit analyses on the electoral appeal of populist parties to only one of these sources, as they might strongly diverge. If data allow, ideally, both sources should be combined to arrive at a comprehensive assessment of the electoral appeal of populist parties.

Authors on populist voting have developed a large number of theoretical approaches in efforts to understand what exactly might lead to this kind of voting behavior. Dovoters fear European integration, are they dissatisfied with the way the courts function, or do they feel themselves as the victims of an economic downturn? None of these explanations, however, proves to be very powerful in explaining a populist vote. Two elements provide the bulk of the explained variance: a negative evaluation of the political system, and anti-immigrant sentiments, and it is not always easy to understand the cognitive logic behind these judgments. Previous studies have indicated that there is not a direct relation between 
satisfaction with government services that are provided, and the level of political trust (Hetherington \& Rudolph 2008). It is equally clear that there is no relation between the presence of ethnic minorities in society, and the level of anti-immigrant sentiments (Hooghe, Reeskens, Stolle \& Trappers 2009). This of course raises a new question: if anti-immigrant sentiments and political distrust can have such important electoral consequences, it becomes all the more important to try to understand the causes of these two attitudes. The dominant idea that populism offers a vote for the 'losers' of structural transformation processes has to be qualified given our results. Admittedly, the element of 'losing' should be further developed. Specific groups of the population might feel at risk, as a result of globalization process. The standard indicators for social stratification (such as income, economic situation, education level, unemployment experiences) apparently do not help us to identify this group of potential 'losers', and other indicators in this regard might be called for. Simultaneously our analysis suggests that objective indicators do not clearly determine the likelihood of a populist vote. Even if we can correctly identify the losers of social change, subjective assessments still might play a role in the decision to cast a populist vote. For Italy at least, dissatisfaction with the way the Italian political institutions operate is such a powerful voting motive that it dwarfs all other potential populist voting motives.

\section{References}

Akkerman, A./C. Mudde/A. Zaslove (2014). How Populist Are the People? Measuring Populist Attitudes in Voters, in: Comparative Political Studies, Vol. 47(9), I24I353.

Alonson, S./C.R. Kaltwasser (2015). Spain: No Country for the Populist Radical Right?, in: South European Society and Politics, Vol. 2O(I), 2I-45.

Auriemma, M/ E. Esposito/E. Iadiciccio/F. Marrazzo/A. Polimene/G. Punziano/G. Sarnelli (2015). Euroscetticismo a 5 Stelle: Stili comunicativi e online text data nel caso delle elezioni europee 2014, in: Sociologia della Communicazione, Vol. 49(I), 36-54.

Bengtsson, ̊̊./K. Hansen/Ó. P Harðarson./H. M. Narud/H. Oscarsson (2014). The Nordic Voter. Myths of Exceptionalism, Colchester.

Bentivegna, S. (20I4). Beppe Grillo's dramatic incursion into the Twittersphere: Talking politics in 140 characters, in: Contemporary Italian Politics, Vol. 6(I), 73-88.

Biorcio, R. (20I4). The reasons for the success and transformations of the 5 Star Movement, in: Contemporary Italian Politics, Vol. 6(I), 37-53.
Bordignon, F./L. Ceccarini (2OI3). Five Stars and a Cricket. Beppe Grillo Shakes Italian Politics, in: South European Society and Politics, Vol. I8(4), 427-449.

Bermeo, N./L. Bartels (eds.) (20I4). Mass politics in tough times. Opinions, Votes, and Protest in the Great Recession, Cambridge.

Caruso, L. (2015). Il Movimento 5 Stelle e la fine della politica, in: Rassegna Italiana di Sociologia, Vol. 56(2), 315-340.

Colloca, P./P. Corbetta (2OI4). Gli elettori del Movimento 5 Stelle sono di destra o di sinistra?, in: Il Mulino, Vol. I4(3), 374-382.

Dancygier, R./M. Donnelly (20I4). Attitudes toward Immigration in Good times and Bad, in N. Bermeo/L. Bartels (eds.), Mass Politics in Tough Times, Cambridge, I48I84.

Druke, H. (2012). Italien: Wirtschaft, Gesellschaft, Politik, Wiesbaden.

ESS Round 6 (2012): European Social Survey Round 6 Data. Data file edition 2.I. Norwegian Social Science Data Services, Norway - Data Archive and distributor of ESS data.

Fuchs, D./O. Gabriel/K. Völkl (2002). Vertrauen in politische Institutionen und politische Unterstützung, in: Österreichische Zeitschrift für Politikwissenschaft, Vol. 3I(4), 427-450.

Hetherington, M./Th. Rudolph (2008). Priming, Performance, and the Dynamics of Political Trust, in: Journal of Politics, Vol. 70(2), 498-512.

Hooghe, M. (20II). Why there is Basically only One Form of Political Trust, in: British Journal of Politics and International Relations, Vol. I3(2), 269-275.

Hooghe, M./S. Marien/T. Pauwels (2OII). Where Do Distrusting Voters Turn if There is No Viable Exit or Voice Option? The Impact of Political Trust on Electoral Behaviour in the Belgian Regional Elections of June 2009, in: Government and Opposition, Vol. 46(2), 245-273.

Hooghe, M./T. Reeskens/D. Stolle/A. Trappers (2009). Ethnic Diversity and Generalized Trust in Europe. A CrossNational Multi-Level Study, in: Comparative Political Studies, Vol. 42(2), 198-223.

Jagers, J/S. Walgrave (2007). Populism as a Political Communication Style. An Empirical Study of Political Parties' Discourse in Belgium. European Journal of Political Research, Vol. 46(3), 319-345.

Kaltwasser, C.R. (2012). The ambivalence of populism: threat and corrective for democracy, in: Democratization, Vol. 19(2), 184-208.

Kessel, S. van (201I). Explaining the Electoral Performance of Populist Parties: The Netherlands as a Case Study, in: Perspectives on European Politics and Society, Vol. I2(I), 68-88.

Kriesi, H. (20I4). The Populist Challenge, in: West European Politics, Vol. 37(2), 36I-378. 
Kriesi, H./E. Grande/M. Dolezal/M. Helbling/D. Höglinger/S. Hutter (20I2). Political conflict in Western Europe, Cambridge.

Lanzone, M. (20I4). The "Post-Modern" Populism in Italy: The Case of the Five Star Movement, in: B. Wejnert/D. Woods (eds.), The Many Faces of Populism: Current Perspectives, Bingley, 53-78.

Marquart, F. (20I3). Rechtspopulismus im Wandel. Wahlplakate der FPÖ von 1978-2008, in: Österreichische Zeitschrift für Politikwissenschaft, Vol. 42(4), 353$37 \mathrm{I}$.

Mayer, N. (1999). Ces français qui votent FN, Paris.

Mayer, N. (2015). The Closing of the radical right gender gap in France?, in: French Politics, Vol. I3(4), 39I-4I4.

McGann, A./H. Kitschelt (2005). The Radical Right in The Alps: Evolution of Support for the Swiss SVP and Austrian FPÖ, in: Party Politics, Vol. II(2), I47-I7I.

Mudde, C./C.R. Kaltwasser (eds.) (20I2). Populism in Europe and the Americas. Threat or Corrective for Democracy? Cambridge.

Newell, J. (2010). The Politics of Italy, Cambridge.

Priester, K. (2OI2). Rechter und linker Populismus. Annäherung an ein Chamäleon, Frankfurt.

Rooduijn, M./S. De Lange/W. Van der Brug (20I4). A populist Zeitgeist? Programmatic contagion by populist parties in Western Europe, in: Party Politics, Vol. 2O(4), 563-575.

Rooduijn, M./T. Pauwels (20II). Measuring Populism: Comparing Two Methods of Content Analysis, in: West European Politics, Vol. 34(6), I272-I283.

Rydgren, J./P. Ruth (20I3). Contextual explanations of radical right-wing support in Sweden: socioeconomic marginalization, group threat, and the halo effect, in: Ethnic and Racial Studies, Vol. 36(4), 7II-728.

Schumacher, G./M. Rooduijn (2013). Sympathy for the 'devil'? Voting for populists in the 2006 and 2010 Dutch general elections, in: Electoral Studies, Vol. 32(I), I24-I33.

Semyonov, M./R. Raijman/A. Gorodzeisky (2006). The Rise of Anti-foreigner Sentiment in European Societies, I988-2000, in: American Sociological Review, Vol. $7 \mathrm{I}(3), 426-449$.

Stockemer, D./A. Amengay (2015). The Voters of the FN under Jean-Marie Le Pen and Marine Le Pen: Continuity or Change?, in: French Politics, Vol. I3(4), 370-390.

Taggart, P. (2000). Populism, Buckingham.

Tournier-Sol, K. (2015). Reworking the Eurosceptic and Conservative Traditions into a Populist Narrative: UKIP's Winning Formula?, in: Journal of Common Market Studies, Vol. 53(I), I40-I56.

Van der Pas, D./C. De Vries/W. van der Brug (20I3). A leader without a party: Exploring the relationship between Geert Wilders' leadership performance in the media and his electoral success, in: Party Politics, Vol. 19(3), 458-476.
Vignati, R. (2015). The Organization of the Movimento 5 Stelle: A Contradictory Party Model, in: F. Tronconi (ed.), Beppe Grillo's Five Star Movement, Aldershot, 29-52.

Webb, P./T.Bale (20I4). Why Do Tories Defect to UKIP? Conservative Party Members and the Temptations of the Populist Radical Right, in: Political Studies, Political Studies, Vol. 62(4), 96I-970.

Zhirkov, K. (20I4). Nativist but not alienated. A comparative perspective on the radical right vote in Western Europe, in: Party Politics, Vol. 2O(2), 286-296.

\section{Authors}

Marc Hooghe is a professor of political science at the University of Leuven (Belgium). He has published mainly on participation and political attitudes, and he holds an ERC Advanced Grant to investigate the democratic linkage between citizens and the state.

Jennifer Oser is an assistant professor of Politics and Government at Ben-Gurion University (Israel), and conducted research on inequality and political participation as a visiting scholar at Harvard University. She has published mainly on topics of political behavior and public policy. 